\title{
THE EFFECT OF CORRUPTION AND COUNTRY RISK ON FDI INFLOWS: EMPIRICAL EVIDENCE FROM DEVELOPING COUNTRIES
}

\author{
Salih TÜREDi ${ }^{1}$
}

\begin{abstract}
The aim of this study is to empirically analyze the effect of corruption and country risk on foreign direct investment (FDI) inflows. The study was carried out using the data of 49 developing countries for the 20022015 period. Relationships between the variables were investigated by static and dynamic panel data methods. This empirical analysis revealed the following general findings: i) a decline in corruption and country risk positively affects FDI inflows; ii) financial risk, which is a component of country risk, has no significant effect on FDI inflows, whereas a fall in the level of economic and political risk accelerates FDI inflows; iii) FDI inflows are most sensitive to economic risk. Based on these results, it can be said that developing countries can attract more FDI by creating a quality institutional structure, effectively fighting corruption, and creating sound macroeconomic policies that improve the investment climate and reduce cost, uncertainty, and risk perception.
\end{abstract}

Keywords: Corruption, Country risk, FDI, Panel data, Developing countries

JEL Codes: D73, D81, F21, C33, 011

\section{YOLSUZLUK VE ÜLKE RISKININ DYY GIRiŞLERi ÜZERINDEKI ETKISi: GELIŞMEKTE OLAN ÜLKELERDEN AMPIRIK KANIT}

\section{Öz}

Bu çalışmanın amacı, yolsuzluk ve ülke riskinin doğrudan yabancı yatırım (DYY) girişleri üzerindeki etkisini ampirik olarak analiz etmektir. Gelişmekte olan 49 ülkenin 2002-2015 dönemine ait verileri kullanılarak yapılan çalışmada, değişkenler arasındaki ilişkiler statik ve dinamik panel veri yöntemleri ile araştırılmıştır. Ampirik analizin ortaya koyduğu genel bulgulara göre; i) yolsuzluk ve ülke riskindeki azalma DYY girişlerini yönde pozitif etkilemektedir. ii) ülke riskinin bileşenlerinden finansal risk DYY girişleri üzerinde anlamlı etki yaratmazken, ekonomik ve politik risk düzeyindeki azalma DYY girişlerini hızlandırmaktadır. iii) DYY girişleri en çok ekonomik riske karşı duyarlıdır. Bu sonuçlardan hareketle, gelişmekte olan ülkelerin daha fazla DYY çekebilmelerinin kaliteli bir kurumsal yapının oluşturularak yolsuzluklarla etkin biçimde mücadele edilmesinin yanı sıra, yatırım ortamını iyileştirici, maliyet, belirsizlik ve risk algııını azaltıcı sağlam makroekonomik politikalar yoluyla mümkün olabileceği ifade edilebilir.

Anahtar kelimeler: Yolsuzluk, Ülke riski, DYY, Panel veri, Gelişmekte olan ülkeler JEL Kodları: D73, D81, F21, C33, O11

${ }^{1}$ Assoc. Prof. Recep Tayyip Erdogan University, Faculty of Economics and Administrative Sciences, Department of Economics, salih.turedi@erdogan.edu.tr, ORCID:0000-0001-6294-1007 


\section{Introduction}

In general, the concept of foreign investment refers to the movement of capital among countries. Due to developments in information and communications technology and the effect of globalization, there has been a significant increase in capital flows throughout the world, especially since the 1990s. Short-term capital movements that take place in the form of buying and selling securities, such as foreign government bonds, stocks, and commercial papers, are called portfolio investments. On the other hand, long-term capital movements that take place in the form of physical capital investments, such as the establishment of new facilities, the purchase of buildings, machinery, equipment, and so on, for the purpose of production in a foreign country by nonresident investors and/or multinational enterprises (MNEs) are called FDI.

These capital movements can provide significant benefits to host-country economies, but they can also bring serious risks if they are not properly managed (López-Mejía, 1999; IMF, 2008: 4). In this context, the positive effects of portfolio investments are the creation of foreign currency inflows, the deepening and expansion of the financial market with increasing liquidity, lowering financial costs by alleviating financial constraints of firms, increasing international financial integration, improving the regulatory and supervisory framework of the domestic capital market, contributing to efficient allocation of capital, and improving the quality of domestic financial services (Pal, 2006: 3; Duasa and Kassim, 2009: 110; Prasad et al., 2003: 25). However, these investments can easily be pulled from the the country when the economy of the host country deteriorates, or when there is a change in the investors' perception in this direction. Rapid and massive capital outflows can lead to financial and economic crises by disturbing stability in developing countries with weak financial markets, creating fluctuations in the money supply, exchange rates, and the stock market. For this reason, portfolio investments are considered a source of instability by developing countries and are not preferred because they are not directly aimed at production and are highly speculative and volatile (Busse and Hefaker, 2007: 297; Elekwa et al., 2016: 81).

On the other hand, theoretical approaches to both topic and country observations reveal that FDIs, which are more stable, long-term, and directly aimed at production compared to portfolio investments, have stronger positive effects on host-country economies and, therefore, are the primarily preferred kind of foreign investment. Accordingly, FDI speeds up economic growth in host countries by providing capital, creating employment opportunities, strengthening competition in domestic markets, facilitating transfers of technology, management skills and managerial experience, improving domestic enterprises' possibilities of getting into international markets, and providing tax revenue and productivity growth (Quazi et al., 2014: 1; Azam and Ahmad, 2013: 3462; Ali et al., 2014: 54; Kariuki, 2015: 346; Popescu, 2014: 8150). Because of these advantages, FDI is considered an important external source for financing growth and development in developing countries, where the level of savings and thus capital accumulation are insufficient. Nevertheless, the theoretical literature contains a general finding that MNEs prefer countries with particularly sound economic fundamentals. In this context, macroeconomic factors that accelerate FDI inflows by increasing the attractiveness of a country are larger market size, macroeconomic stability, skilled labor, high economic growth and trade openness, technological infrastructure, and low labor costs (Ohlsson, 2007: 6-7; Azam and Khattak, 2009: 47; Vijayakumar et al., 2010: 5; Hossain, 2016: 256). Another general finding in the literature is that strong macroeconomic fundamentals of a host country may not be sufficient on their own to provide the desired FDI inflow, and institutional factors such as institutional quality, political stability, civil liberties, political rights, democracy, quality of bureaucracies, and rule of law are decisive in investment decisions, and therefore in FDI inflows (Borensztein et al., 1998; Li and Resnick, 2003; Egger and Winner, 2005; Choi and Samy, 2008). To sum up, the amount of FDI inflow differs depending on the economic, political, and institutional environment of the host countries. 
The literature on the determinants of FDI and its effect on host countries also focuses in recent years on corruption and country risk. From a theoretical approach, it can be said that corruption and country risk are undesirable phenomena for investors (domestic or foreign). From this point of view, country risk and corruption levels in countries are among the factors that are considered in the investment process by MNEs moving with high return motive. On the other hand, it is also observed in the theoretical and empirical literature that no consensus has been reached yet on the effects of these variables on FDI. The present study aims to investigate the effects of corruption and country risk and its components (economic, political, and financial risk) on FDI inflows in developing countries. It is expected that the study, which differs from similar studies in terms of period, the countries studied, and the variety of econometric methods used, will contribute to debates in the literature. In this context, the second section mentions the theoretical debates about the relationship between the variables; the third section presents the previous empirical studies on the subject in chronological order; the fourth section introduces the data used in the analysis; the fifth section explains the econometric method employed; the sixth section contains estimation findings; and the seventh, and last, section includes conclusions and recommendations.

\section{Theoretical Literature Review}

\subsection{The Relationship between Corruption and FDI Inflows}

Although corruption is seen more in underdeveloped and developing countries, it is a global problem that, far beyond a national or regional problem, can be encountered in all countries. While there are many different definitions in the theoretical literature, definitions of corruption by Transparency International (TI) and the World Bank (WB) are the most sought-after. The WB defines corruption as "the abuse of public power for private gain" (WB, 2000:137) and the definition of corruption by $\mathrm{Tl}$ is as follows: "the abuse of entrusted power for private gain" (www.transparency.org, 2017). Though corruption is mostly observed in the form of bribery, it also involves activities such as extortion, fraud, embezzlement, nepotism, cronyism, influence peddling, rent-seeking, money-laundering, and kickbacks (Balboa and Medalla, 2006: 2; Ravi, 2015: 101). According to Amundsen (1999), corruption is a disease that destroys the functioning of vital organs by negatively affecting the social, political, cultural, and economic structure of a society. This is because it weakens the quality of governance and the efficiency of public policies, destroys the efficient distribution of resources, prevents the development of the private sector (Amundsen, 1999: 1). With a similar approach, the WB notes that corruption is one of the biggest obstacles to economic and social development because it undermines the rule of law and weakens the institutional foundation on which economic growth is based (Worldbank, 2017). Because of these effects, the causes and consequences of corruption are one of the main concerns of policy makers and economists. The relationship between corruption and FDI is also a matter of hot debate. The theoretical literature on the effect of corruption on investment decisions of foreign investors contains two opposing views: the grabbing-hand theory of corruption and the helping-hand theory of corruption.

The grabbing-hand theory, which posits a negative relationship between corruption and FDI, addresses the issue based on the concept of cost. According to the theory, the necessity to bribe to get privileged access to markets, obtain government permits and licenses, or win profitable foreign contracts creates an extra cost to foreign investors. In this way, just like a tax, corruption decreases the expected return/profit of an investment project by increasing the cost of doing business, disrupting the allocation of resources, and creating ambiguity, thus deterring foreign investors, whose main goal is to gain profit, and decreasing FDI inflows. Moreover, corruption negatively affects the other determinants of FDI, such as economic growth, productivity of public investment, and quality of infrastructure, having an indirect negative effect on FDI inflows (AlSadiq, 2009: 267-269; Alemu, 2012: 389-390; Castro and Nunes, 2013: 62; Quazi, 2014: 232). On the other hand, some argue that corruption does not definitely reduce FDI inflows. This argument is based on the fact that some developed and developing countries known to have high levels of 
corruption also attract a high amount of FDI. For instance, Habib and Zurawicki (2002) and Teixeira and Guimarães (2015) report that Mexico, Brazil, Indonesia, Italy, Poland, Russia, China, Thailand, Argentina, Malaysia, Belgium, and India have attracted high amounts of FDI in recent years despite high levels of corruption. This situation, where corruption is considered as a factor encouraging FDI inflows rather than reducing them, is explained by the helping-hand theory of corruption. According to this theory, corruption can be an effective "lubricant," especially in countries with a weak institutional structure and rigid red tape (Quazi, 2014: 231; Fahad and Ahmed, 2016: 3). To put it more clearly, corruption activities, such as bribery, nepotism, etc., function as "speed money," thus relieving investors from burdensome government regulations and bureaucratic barriers and helping them get the job done more quickly (Quazi et al., 2014: 2; Brada et al., 2012: 641). In this way, MNEs can capture financial benefits from the host countries that cannot be obtained through export, such as profitable contracts with the government, subsidies, permits and licenses, and tax incentives. This situation, which is extremely profitable for MNEs that obtain almost monopoly power in the host country, provides a great incentive for MNEs to bribe host government officials. Therefore, this theory argues that countries with high corruption are more preferred by MNEs (Kendall and Zhou, 2009: 3; Barassi and Zhou, 2012: 302-303).

\subsection{The Relationship between Country Risk and FDI Inflows}

The concept of risk can be defined as the probability that an unforeseen event will occur. All business transactions involve risk. However, when these transactions occur across international borders, they have additional risks, called country risk, which arise from ambiguities in the political, financial, and economic structure of countries (Midoun and Zairi, 2015: 19). These risks are among the most important determinants of the investment decisions of MNEs. With uncertainties such as instability, crisis, etc., which negatively affect the investment climate in a country where an investment is planned, it is not possible for the FDIs to abandon the host country easily. Therefore, there is a close relationship between a country's risk level and FDI inflows. The International Monetary Fund (IMF) shares a similar view, arguing that international investments provide various opportunities for investors but investors do not take advantage of these opportunities fully due to information asymmetry, preferences for home assets, transaction costs, and high risk aversion. The IMF considers a high country risk as a factor that affects international investors' motivation and investment strategies (IMF, 2014: 5). Country risk is variously defined in the literature. For example, Shapiro (1999) defines country risk as the general level of political and economic uncertainty in a country affecting the value of its investments. To White and Fan (2006), country risk is the unexpected "downside" variability in a key performance indicator, or significant strategic target, which results from engaging in international business transactions. Finally, Elleuch et al. (2015) defines country risk as the possibility that a country is unable or unwilling to fulfill its obligations due to economic, political, social, or other specific conditions of the country. In short, country risk refers to all potential risks that investors may encounter in the country in which they plan to make an investment, and it can be classified into economic, financial, political, and cultural risk (White and Fan, 2006: 155).

\subsubsection{Economic Risk}

Economic risk refers to a significant change in the economic structure that produces a major change in the expected return of an investment (Meldrum, 2000: 35). From a more general point of view, economic risk is defined as the probability that an investment is affected by macroeconomic conditions, and it is an important indicator for MNEs. The economic risk level of a country is estimated by taking account of such variables as the per capita GDP, real GDP growth, inflation rate, budget balance, current account balance, and exchange rate (PRS, 2014). Any positive or negative change in these macroeconomic indicators affects foreign investors' perception of economic risk in the host country. For instance, unpredictable and high inflation rates are considered by foreign investors as a sign that the host country is not successful at balancing its budget and implementing a stable monetary policy. Since it creates uncertainty and reduces the 
real value MNEs' assets and gains, high inflation increases a country's economic risk levels while reducing FDI inflows. Similarly, exchange rate risk is a macroeconomic risk due to its effect on the cost/profitability of investments. Appreciation of the host country's currency affects FDI inflows adversely since it increases prices and costs and reduces profitability (Al-Jaifi et al., 2016: 91-92). However, the main problem for investors is not the direction of the change in the exchange rate (appreciation or depreciation), but the speed of the change. High volatility creates uncertainty and makes it difficult for investors to make investment decisions.

\subsubsection{Financial Risk}

Financial risk is defined as the risk that a country may be unable to fulfill its foreign obligations. Undoubtedly, countries with high financial risk are very likely to experience a financial crisis. In the case of deteriorating financial conditions of the host country, as opposed to other forms of foreign capital (short-term bank loans, portfolio investment), FDIs can not abandon the country easily. Therefore, foreign companies are extremely sensitive to the financial risk level of the host country (Midoun and Zairi, 2015: 20). Foreign debt and other variables, such as current account balance, net international liquidity. and exchange rate stability are used to measure financial risk, which is an important indicator of the capacity of financial markets and stability of a country (PRS, 2014). As the share of a country's foreign debt in GDP increases, financial risk increases, reducing the country's ability to pay back its debts. Thus, countries with high levels of debt are less attractive to MNEs for investment. In this sense, a large, chronic current account and a budget deficit for many years are one of the main reasons for increases in foreign debt and the financial risk level of countries (Hakayawa, et al., 2011: 5; Ali, et al., 2014: 55). Therefore, increased financial risk, which is the indicator of a deteriorating financial state of a host country, deters FDI inflows.

\subsubsection{Political Risk}

Political risk can be defined as governmental or societal actions and policies, originating either within or outside the host country, that negatively affecting foreign business operations and investments (Desbordes, 2010: 94). As the definition indicates, the main problem of political risk in terms of foreign investors is the negative effect it has on "profitability." From this point of view, political risk factors that can be encountered in developing countries include nationalization or expropriation of foreign assets, arbitrary government regulations related to FDI policies (permitted number of non-host personnel, profit transfer amount, and restrictions on sectors for investment), war, terrorism, political violence, red-tape bureaucracy, long delays in getting permits, price checks, common corruption, and environmental regulations (Wyk and Lal, 2008: 513; Elleuch et al., 2015: 14437; Baek and Qian: 2011: 6). Given the fact that institutional quality is a determinant of location preferences of MNEs, we can say that the existence of political risk factors, which are both an indicator and a result of low institutional quality in a host country, creates ambiguity and increases costs, thus reducing the efficiency of foreign companies and making it hard for them to do business (Hakayawa, et al., 2011: 5). Just like other risks, political risk deters FDI inflows.

\section{Empirical Literature Review}

\subsection{The Relationship between Corruption and FDI Inflows}

The empirical literature comprises mixed evidence about the impact of corruption on FDI inflows. In this regard, studies can be classified into three groups: (i) studies in which corruption affects FDI inflows negatively (i.e., studies supporting the grabbing-hand theory), (ii) studies in which corruption affects FDI inflows positively (i.e., studies supporting the helping-hand theory), and (iii) studies that report no relationship between corruption and FDI.

Wei (1997) points out a negative relationship between corruption and FDI. To Wei (1997), countries with high corruption levels do not seem attractive to foreign investors because corruption creates a high degree of uncertainty, negatively affecting the return on investment and reducing FDI inflows. Abed and Davoodi (2000) examine the effect of corruption and structural 
reforms on per capita FDI inflows in 25 transition economies and find that countries with a low level of corruption attract more per capita FDI. However, when they include a "structural reform" factor in the estimation models, corruption becomes insignificant. According to them, this finding shows that structural reforms are more important in attracting FDI inflows than reducing the level of corruption. Alemu (2012) performs a panel data analysis of 16 Asian countries and reports that there is a negative relationship between corruption and FDI. A $1 \%$ decrease in the level of corruption increases FDI inflows in these countries by 9.1\%. Azam and Ahmad (2013) examine 33 less-developed countries using fixed effect panel estimation and find that corruption negatively affects FDI inflows into the host country. The authors conclude that "corruption raises business costs and reduces the incentives to invest. Therefore, MNEs stay away from countries where a high level of corruption is prevalent". Ohlsson (2007) tests which FDI inflows are affected by corruption by comparing FDI from different developed countries (USA, Europe and Japan) to developing countries (46 countries). The results of the regression analysis show that: i) corruption is a significant variable, and it does have a negative effect on total FDI, and ii) capital from the USA is most sensitive to corruption. Based on these findings, the author concluds that corruption has a negative impact on FDI and quality of life; thus public policies should aim to reduce corruption. Emphasizing that countries with a low level of corruption are likely to attract more FDI since they provide a more suitable climate for investors, Castro and Nunes (2013) find evidence that supports their view as a result of their analysis of 73 countries, including emerging markets, as well as developing and developed economies. They indicate that keeping corruption under control might be an important strategy for increasing FDI inflows. Hossain (2016) examines the relationship between corruption and FDI in 48 countries in South and South-East Asia, Latin America, the Caribbean, and Africa. He reports that the reduction of corruption boosts the confidence of investors, decelerates business costs, and amplifies transparence and accountability, thus accelerating FDI inflows.

Egger and Winer (2005) examine 73 less-developed and developed countries and find that there is a positive relationship between corruption and FDI. They indicate that corruption is an incentive for FDI inflows. Tokunova (2014) investigates the relationship between corruption and FDI in developed (the USA, the Netherlands, the UK, Japan) and developing countries (India, China, Russia, Brazil), and finds that the relationship changes depending on the development level of the countries, in that corruption does not have any effect on FDI in developing countries, but it affects FDI inflows positively in developed countries. The author draws the economic conclusion that "countries with a high level of corruption attract more FDI compared to the countries with a low level of corruption". Contrary to Tokunova (2014), Ardiyanto (2012) reports that corruption has a negative effect on FDI in developed countries but a positive effect on FDI in developing countries. Helmy (2013) uses panel data from 21 MENA countries and obtains empirical findings similar to those found by Ardiyanto (2012). He concludes that FDI varies positively with corruption in the countries studied. Therefore, policies for combatting corruption should be based on sound legal procedures that do not infringe the rights, freedom, and security of investors.

On the other hand, Akçay (2001) uses the data of 52 developing countries and reports that corruption does not have a significant impact on FDI inflows and that market size, corporate tax rate, labor cost, and openness are the most powerful determinants of FDI in the countries studied. Jadlav (2012) examined the economic, political, and institutional determinants of FDI in BRICS and found that trade openness, market size, and natural resource availability are FDI's economic determinants, while rule of law, voice, and accountability are FDI institutional and political determinants in the countries studied. Defined as an institutional factor, corruption was not found to be a significant determinant of FDI.

\subsection{The Relationship between Country Risk and FDI Inflows}

A review of the empirical literature shows that no consensus has been reached yet on the relationship between country risk and FDI inflow. Empirical studies examining different countries 
and periods with different estimation methods provide some evidence that there is no relationship or a positive relationship between country risk and its components (economic, financial, and political) and FDI inflow. However, the findings of most studies suggest that there is a negative relationship between these variables. For example, Ramcharran (1999) examines 26 developing countries in Eastern Europe, Latin America, Asia, and Africa using regression analysis and cross section data and finds that country risk affects FDI inflows negatively. Carstensen and Toubal (2004) examine the determinants of FDI flows from the OECD countries to Central and Eastern European countries (CEECs) during their transition towards a market economy. The results of their analysis reveal that the traditional determinants, such as market potential, low relative unit labor costs, a skilled workforce, and relative endowments, have a significant and plausible effect on FDI. Their findings also show that country risk is a deterrent of FDI inflows since it creates uncertainty. Lee and Rajan (2009) examine the determinants of bilateral FDI flows to and from APEC economies using the gravity model approach and find that economies with lower country risk appear to attract more FDI inflows. Their results indicate that the most important component of this risk pertains to political risk (as opposed to financial or economic risks). Musonera (2008) points out that FDI flows into sub-Saharan Africa (SSA) are dismally low and attributes these low levels of FDI flow into SSA to the risky business/investment climate of the region. The results of his rigorous regression analysis reveal that FDI inflows significantly depend on the risk level (especially political risk) of the host country. He suggests that SSA countries should implement policies that would reduce risk levels to attract more FDIs. Hakayawa et al., (2011) examine 93 countries (63 of which were developing countries) and report that high levels of political risk reduce FDI inflows, while the level of financial risk does not have a significant effect on FDI. Based on their findings, they also suggest that MNEs do not take financial risk levels of host countries into account. A similar finding regarding developing countries is shared by Topal and Gül (2016). The results of their analysis, which uses a two-step system GMM estimator, show that: i) reduced country risk increases FDI inflow, and ii) financial risk has an insignificant effect on FDI inflows, while economic and political risk have a negative and significant effect on FDI.

Jiménez (2011) examines the determinants of FDI flows from the Southern European countries to the countries in North Africa and Central and Eastern Europe. To Jiménez (2011), political risk and FDI are positively correlated, i.e., greater levels of political risk do attract higher FDI inflows. Sedik (2012) obtained a similar finding in their study on MENA countries. They report that economic and financial risk have a positive but insignificant effect on FDI, while political risk unexpectedly has a positive and significant effect on FDI inflows. Sanjo (2012) uses a two-country model with different risk levels and market sizes and finds that what is important for a foreign firm is whether the host country's market size is sufficiently large, rather than whether the host country is high-risk or low-risk. If the market size of the high-risk country is sufficiently large relative to the low-risk country, the foreign firms prefer the high-risk country for investment. Finally, Kariuki (2015) investigates the determinants of FDI in African countries and reports that i) a high economic risk has a negative and significant effect on FDI flows into Africa, and ii) political risk and financial risk have a negative but insignificant impact on FDI inflows.

\section{Data}

In this study, which examines the effect of corruption and country risk on FDI inflows, we use data for 49 developing countries ${ }^{2}$ for the period from 2002-2015. The countries included in the study were determined using the IMF's classification of countries based on their development level. Estimation models include not only the variables of "corruption" and "risk", but also some other control variables that were proven effective on FDI inflows with strong empirical evidence.

\footnotetext{
${ }^{2}$ Armania, Argentina, Azerbaijan, Bangladesh, Belarus, Bolivia, Bostwana, Brazil, Bulgaria, Chile, China, Costa Rica, Crotia, Dominican, Ecuador, Egypt, El Salvador, Ghana, Honduras, Hungary, India, Indonesia, Jamaica, Lebanon, Lithuania, Malaysia, Mali, Mexico, Moldowa, Morocco, Namibia, Nigeria, Oman, Pakistan, Panama, Paraguay, Peru, Philippines, Qatar, Romania, Russia, Senegal, Sierra Leone, South Africa, Sri Lanka, Trinidad \& Tobago, Tunusia, Turkey and Ukraine.
} 
The data on FDI and the control variables, i.e., Inflation, Population, GDP, Trade Openness, and Physical Capital, were obtained from the WB's World Development Indicators [WDI] database, while the data on Control of Corruption and Rule of Law were taken from WB's World Governance Indicators [WGI $]^{3}$ database. The data on country risk and its components were received from PRSICRG $^{4}$ (Political Risk Services-International Country Risk Guide). Explanatory information about the variables is given below:

FDI: Foreign direct investment inflows measured in US dollars at current prices [\$ billion].

Country Risk Index: This index is calculated as follows: 0.5 (Political risk + Economic Risk + Financial Risk). The general country risk index has a range between [0] and [100]. A higher index value indicates a lower level of country risk.

Political Risk Index: This index measures the political risk level of countries. The index value has a range between [0] and [100]. A higher index value indicates a lower level of political risk.

Economic Risk Index: This index measures the strengths and weaknesses of economies and has a range between [0] and [50]. Index value is inversely proportional to the economic risk level of countries. [0] indicates the highest level of economic risk while [50] indicates the lowest level of economic risk.

Financial Risk Index: This index measures the countries' ability to fulfill their official, commercial, and financial obligations. The index has a range between [0] and [50]. A higher index value indicates higher ability to fulfill obligations and a lower level of financial risk.

Inflation: Annual percent change in consumer prices.

Population: Total population.

Control of Corruption Index: This index measures the corruption level and the perception of the extent that public power is used for personal interests, as well as to what extent the institutional structure of a country is effective in preventing and combatting corruption. The index has a range between [-2.5] and [+2.5]. A higher index value indicates increased power to combat and decreased perception of corruption, and thereby corruption.

GDP: Gross domestic product in US dollars at current prices [\$ billion].

Rule of Law Index: Rule of law captures perceptions of the extent to which agents have confidence in and abide by the rules of society, and in particular the quality of contract enforcement, property rights, the police, and the courts, as well as the likelihood of crime and violence. [-2.5] indicates that rule of law is weakest, while [2.5] indicates rule of law is strongest.

\section{Econometric Methodology}

We used static and dynamic panel data analysis to examine the empirical relationship between the variables. Panel data analysis has some advantages, such as having a greater number of observations and more degrees of freedom and allowing for less linearity between explanatory variables and the observation of omitted (unobservable and missing) individual effects. Due to such advantages, panel data analysis is more effective in estimating complex relationships than time series data analysis and cross sectional data analysis. Therefore, panel data analysis has been frequently used in the empirical literature (Hsiao, 2003: 3; Baltagi, 2005: 4-7). A standard linear panel regression model can be shown as follows:

$y_{i t}=\beta_{0}+\beta_{1 i t} \chi_{1 i t}+\beta_{2 i t} \chi_{2 i t}+\ldots+\beta_{k i t} \chi_{k i t}+\varepsilon_{i t}$

${ }^{3}$ For detailed information about the WGI methodology, see https://papers.ssrn.com/sol3/papers2.cfm?abstractid=1682130 ${ }^{4}$ For detailed information about the ICRG risk methodology, see http://www.prsgroup.com/about-us/our-two-methodolo gies/icrg 
where $\left(y_{i t}\right)$ denotes the dependent variable; $\left(\beta_{\text {oit }}\right)$ denotes the constant term (intercept); $(\chi)$ denotes k-1 number of independent variables $\left(\beta_{k i t}\right)$ denotes the slope coefficient, and $\left(\varepsilon_{i t}\right)$ denotes the error term, which is independent for all times and units and is assumed to be distributed as $\left[\mu_{i t \sim N N}\left(0, \sigma^{2}\right)\right]$. Again, (i) represents the number of units (cross-sectional dimension of the model) $(i=1,2, \ldots, N)$ and $(t)$ represents the time dimension of the model $(t=1,2, \ldots, T)$.

\subsection{Static Panel Data Analysis}

In static panel data analysis, the relationship between the variables can be analyzed using the Pooled OLS, Fixed Effects Model (FEM), or Random Effects Model (REM), each of which has different assumptions regarding the slope coefficient, constant term, and error terms in Equation (1). Pooled OLS assumes that the constant term, which shows individual effects, and the slope coefficient are the same. In other words, there is no unit and time effect in the estimation model. Assuming that all observations are homogenous and neglecting the potential differences between units makes the efficiency and consistency of Pooled OLS questionable. In this case, FEM or REM, which allow for more flexible assumptions about the unit and time effects in the model, is used. Both models assume that slope coefficients are constant, but the constant term does not vary over time but across units (unit effect), does not vary across units but over time (time effect), or varies both over time and across units (unit and time effect). From this point of view, the models where differences in the constant term are derived from the unit or time effect are called one-way FEM/REM and the models where differences in the constant term are derived from the unit and time effect are called two-way FEM/REM (Hill et al., 2011: 543; Akbar et al., 2011: 149: 2011; Gupta and Singh, 2016: 186).

The main difference between FEM and REM is derived from the assumptions about the relationship between the error term and the independent variables in the model. FEM assumes that the differences between units can be captured through the constant term; therefore FEM allows the individual specific effects $\left(\mu_{i}\right)$ to be correlated with the independent variables $\left(\chi_{i t}\right)$, while also accepting that the independent variables are uncorrelated with the error term. $\left[E\left(\varepsilon_{i t} / \chi_{\text {kit }}\right) \neq 0\right]$. On the other hand, REM assumes that the constant term ( $\left.\beta_{\text {oit }}\right)$ is a random variable, so the differences between units occur randomly, and $\left(\mu_{i}\right)$ is not correlated with the independent variables $\left[E\left(\mu_{i t} / \chi_{k i t}\right) \neq 0\right]$. Finally, REM assumes that the error term and independent variables are correlated $\left[E\left(\varepsilon_{i t} / \chi_{\text {kit }}\right)=0\right.$ ] (Maddala, 2001: 576; Gujarati, 2003: 647; Pfister, 2010: 18).

Some specification tests are run to decide which static panel data method is appropriate for reliably estimating the relationships between variables. This study used the F-test, likelihood ratio (LR) test, and Hausman test to determine the appropriate estimator. The F-test is used to choose between Pooled OLS and FEM, the LR test is used to choose between Pooled OLS and REM, and the Hausman test is used choose between FEM and REM. The F-test is used to test the following null hypotheses: $\left[\left(\mathrm{H}_{0}: \mu_{i}=\gamma_{t}=0\right)\right.$, (there is no unit and time effect)], [( $\left.\mathrm{H}_{0}: \mu_{i}=0\right)$, (there is no unit effect)], and [( $\left.\mathrm{H}_{0}: \gamma_{t}=0\right)$, (there is no time effect)]. If the hypotheses that assume that unit and/or time effects equal zero are rejected at the end of the test, Pooled OLS is confirmed as proper on the grounds that the estimation results might be inconsistent and biased. The LR test is used to test the following null hypotheses: $\left[\left(H_{0}: \sigma_{\mu}=\sigma_{\gamma}=0\right)\right.$ (standard error of the unit and time effect equal zero)], [( $\left.H_{0}: \sigma_{\mu}=0\right)$, (standard error of the unit effect equals zero)], and [( $\left.H_{0}: \sigma_{\gamma}=0\right)$, (standard error of the time effect equals zero)]. If the LR $\left(\chi^{2}\right)$ test statistics are significant, these main hypotheses are rejected, it is accepted that there is a unit and time effect in the model, and Pooled OLS is an inconsistent and inefficient estimator.

In cases where there is a unit and/or time effect in the estimation model and Pooled OLS is found to be not effective, what needs to be done is to decide whether these effects are fixed or random (Tatoğlu, 2012: 179). For this purpose, some tests such as the Wald test, F-test, and t-Test are used in the literature; however, the Hausman (1978) specification test is most frequently used. We employed the Hausman test to choose between FEM and REM. The Hausman test is used to test the null hypothesis [( $\mathrm{H}_{0}: \beta_{0 i t}$ is uncorrelated with $\chi_{\text {kit), }}$ (i.e., REM is consistent and effective)] 
against the alternative hypothesis [ $\left(\mathrm{H}_{1}\right.$ : $\beta_{0 i t}$ is correlated with $\left.\chi_{\text {kit }}\right)$, (i.e., REM is inconsistent and ineffective]. If the significance of the Hausman $\left(\chi^{2}\right)$ test statistics is smaller than 0.05 , the null hypothesis is rejected, and FEM is confirmed as the proper estimator. If the significance of the Hausman $\left(\chi^{2}\right)$ test statistics is greater than 0.05 , REM is preferred.

As it is well known, panel data consists of time-series data $(T)$ and cross-sectional data (N). Therefore, the problems of heteroscedasticity, autocorrelation, and cross-section dependence, which are observed in time-series and cross-sectional analyses and may cause biased statistical findings, can also be observed in the panel data analysis (Gujarati and Porter, 2007: 593-612). Therefore, in order to obtain valid statistical inferences at the end of the analysis, the estimation models should be tested to determine whether they have these problems.

In this study, heteroscedasticity was tested using the Modified Wald test. The null hypothesis $\left(\mathrm{H}_{0}\right)$ assumes the variance of units is homoscedasticity, and rejection of the $\mathrm{H}_{0}$ indicates the presence of heteroscedasticity in the model. To detect the presence of autocorrelation, we performed the Durbin-Watson (DW) test developed by Bhargava, Franzini and Narendranathan (1982) and the locally best unbiased invariant test (LBI) developed by Baltagi-Wu (1999). We do not present critical values for both tests; however, we confirmed the presence of autocorrelation since the test statistics we found were lower than 2 (the threshold level). Finally, the presence of cross-section dependence was detected using the Pesaran CD test and Free's test. In both tests, the null hypothesis [ $\mathrm{H}_{0}$ : no cross-section dependence] is tested against the alternative hypothesis $\left[\mathrm{H}_{1}\right.$ : cross-section dependence]. Rejection of $\mathrm{H}_{0}$ confirms the presence of cross-section dependence in the models. When these problems are present in the models, estimation should be repeated under the assumption of the presence of these problems using estimators that will yield effective results. To estimate the relationship between the variables, four models were used: Model (1) aims to estimate the effect of corruption and country risk on FDI inflows. Models (2), (3), and (4) examine the effect of corruption together with political, financial, and economic risk, respectively.

\section{Model (1):}

$\ln (\text { FDI })_{i t}=\beta_{0}+\beta_{1} \ln (\text { GDP })_{i t}+\beta_{2}(\text { Physical Capital })_{i t}+\beta_{3}(\text { Trade Openness })_{i t}+\beta_{4}(\text { Inflation })_{i t}+\beta_{5}$ In $(\text { Population })_{\text {it }}+\beta_{6}($ Rule of Law Index $)_{i t}+\beta_{7}(\text { Control of Corruption Index })_{i t}+\beta_{8}(\text { Country Risk Index })_{i t}+\varepsilon_{i t}$

Model (2):

In $(\text { FDI })_{i t}=\beta_{0}+\beta_{1} \ln (G D P)_{i t}+\beta_{2}(\text { Physical Capital })_{i t}+\beta_{3}(\text { Trade Openness })_{i t}+\beta_{4}(\text { Inflation })_{i t}+\beta_{5}$ In $(\text { Population })_{i t}+\beta_{6}($ Rule of Law Index $)_{i t}+\beta_{7}(\text { Control of Corruption Index })_{i t}+\beta_{8}(\text { Political Risk Index })_{i t}+\varepsilon_{i t}$

Model (3):

$\ln (\text { FDI })_{i t}=\beta_{0}+\beta_{1} \ln (G D P)_{i t}+\beta_{2}(\text { Physical Capital })_{i t}+\beta_{3}(\text { Trade Openness })_{i t}+\beta_{4}(\text { Inflation })_{i t}+\beta_{5}$ In $(\text { Population })_{i t}+\beta_{6}($ Rule of Law Index $_{\text {it }}+\beta_{7}(\text { Control of Corruption Index })_{i t}+\beta_{8}(\text { Financial Risk Index })_{i t}+\varepsilon_{i t}$

Model (4):

$\ln (\text { FDI })_{i t}=\beta_{0}+\beta_{1} \ln (G D P)_{i t}+\beta_{2}(\text { Physical Capital })_{i t}+\beta_{3}(\text { Trade Openness })_{i t}+\beta_{4}(\text { Inflation })_{i t}+\beta_{5}$ In $(\text { Population })_{i t}+\beta_{6}($ Rule of Law Index $)_{i t}+\beta_{7}(\text { Control of Corruption Index })_{i t}+\beta_{8}(\text { Economic Risk Index })_{i t}+\varepsilon_{i t}$

In all models: $i=1,2, \ldots, 49$. $\quad t=2002, \ldots, 2015$.

\subsection{Dynamic Panel Data Analysis}

Most economic relationships are dynamic in nature, and one of the advantages of panel data is that it allows for the detection of dynamic relationships more easily. A dynamic relationship can be defined as the situation where economic behavior is under the effect of old behaviors to a great extent. Such a relationship is characterized by the presence of lagged variables in the panel data models. From this point of view, the models in which a lagged dependent variable is among the regressors (independent variables) are called dynamic panel data models (Baltagi, 2005, 135; Tatoğlu, 2012: 65). A dynamic panel data model can be shown as follows:

$$
y_{i t}=\delta y_{i, t-1}+\beta x_{i t}+\varepsilon_{i t} \quad i=1, \ldots, N ; \quad t=1, \ldots, T \quad\left[\varepsilon_{i t}=\mu_{i}+v_{i t}\right]
$$


where $\left(y_{i t}\right)$ denotes the dependent variable; $\left(\chi_{i t}\right)$ denotes the independent variable; $\left(y_{i t-1}\right)$ denotes the lagged dependent variable, and $\left(\varepsilon_{i t}\right)$ denotes the error term. Inclusion of the lagged dependent variable on the right hand side of the equation as a regressor brings some problems with it. Since $\left(y_{i t}\right)$ is a function of $\left(\mu_{i}\right),\left(y_{i t-1}\right)$ is also a function of $\left(\mu_{i}\right)$. Therefore, $\left(y_{i t-1}\right)$ is correlated with the error term. Since this means the rejection of the exogeneity assumption, i.e., emergence of the problem of endogeneity, the pooled OLS estimator is rendered biased and inconsistent. Similarly, some argue that estimation of a dynamic model with FEM presents some difficulties. This situation, which emerges especially when $(N)>(T)$, occurs because there are unit effects in the model, and $\left(y_{i t-1}\right)$ which is included in the model as a regressor, is correlated with $\left(\varepsilon_{i t}\right)$. This means the rejection of the FEM hypothesis that "independent variables are not correlated with the error term" $\left[E\left(\varepsilon_{i t} / \chi_{k i t}\right) \neq 0\right]$. To solve this problem, within transformation (i.e., taking the first difference of the original model) is proposed. Within transformation eliminated the unit effect $\left(\mu_{\mathrm{i}}\right)$ in the model. However, since $\left(y_{i t-1}\right)$ and $\left(\varepsilon_{i t}\right)$ are correlated, $\left(y_{i t-1}\right)$ and $\left(v_{i t-1}\right)$ are also correlated, so the problem cannot be solved. For this reason, FEM is biased and inconsistent. Again, the fact that the unit effect $\left(\mu_{i}\right)$, which is a component of the error term, is correlated with $\left(y_{i t-1}\right)$ is not compatible with the REM hypothesis that assumes that unit effect is not correlated with independent variables $\left[E\left(\mu_{i t} / \chi_{k i t}\right) \neq 0\right.$ ]. Therefore, REM is also biased and inconsistent (Bond, 2002: 4-5; Baltagi, 2005: 135136; Baum, 2006: 232-233; Söderbom, 2011: 22; Akay, 2015: 82). Inefficiency of the standard/static methods based on least squares makes it mandatory to estimate the dynamic panel data models with alternative methods. One of the tools most commonly used in the literature in such situations is GMM (generalized methods of moments). There are two different types of GMM: the differenceGMM developed by Arellano-Bond (1991) and the system-GMM developed by Arellano-Bover (1995) and Blundell-Bond (1998). Arellano-Bond (1991) suggests that the problems caused by the inclusion of $\left(y_{i t-1}\right)$ in the model as an independent variable can be solved using instrumental variables. Therefore, difference-GMM takes the first difference of the model to eliminate the unit effect, and then lagged levels of the right-hand-side variables (independent variables) are used as instrument variables (Soto, 2009, 2). On the other hand, Arellano and Bover (1995) and Blundell and Bond (1998) argue that, when the independent variables are persistent over time, lagged levels of these variables are weak instruments for the regression equation in differences (35). From this point of view, the researchers develop the system-GMM, which they suggested is more powerful and effective than the difference-GMM. In this approach lagged differences of $\left(y_{i t}\right)$ are used as instruments for equations in levels, in addition to lagged levels of $\left(y_{i t}\right)$ as instruments for equations in first differences. (Bond et al., 2001: 9; Baltagi, 2005: 148; Li and Zhang, 2007: 112).

The consistency of GMM estimators requires that there is no second-order serial correlation in the first differences of the error terms and validation of instrument variables. Otherwise, the findings will be biased. Thus, before the estimation of relationships among the variables, it must be determined whether the dynamic panel data model satisfies these assumptions or not. AR (1) and AR (2) tests proposed by Arellano-Bond (1991) are used to determine whether the error terms are correlated or not. In the $A R(1)$ test, the hypothesis that "there is no first degree autocorrelation," and in the AR(2) test, "the hypothesis of there is no second degree autocorrelation," are tested. To ensure consistency, the AR (1) test statistics should be significant (probability value $>\mathrm{z}$ smaller than 0.05 ), i.e., the null hypothesis $\left(\mathrm{H}_{0}\right)$ should be rejected, and the AR (2) test statistics should be insignificant (probability value $>z$ greater than 0.05 ), i.e., the null hypothesis $\left(\mathrm{H}_{0}\right)$ should be accepted. Hansen and Sargan tests are used to determine whether the instrumental variables are valid or not. In both tests, the null hypothesis assumes that overidentifying restrictions are valid. If the null hypothesis is accepted as a result of the tests, there is no correlation between instrumental variables and error terms, and these variables are valid. The dynamic panel data models established for the analysis conducted with the two-step DifferenceGMM and two-step System-GMM estimators are shown below. Model (5) examines the effect of corruption and country risk on FDI inflows. Models (6), (7), and (8) examine the effect of corruption together with political, financial, and economic risk, respectively. 
Model (5):

$\operatorname{In}(F D I)_{i t}=\beta_{1} \ln (F D I)_{i t-1}+\beta_{2} \ln (G D P)_{i t}+\beta_{3}(\text { Physical Capital })_{i t}+\beta_{4}(\text { Trade Openness })_{i t}+\beta_{5}(\text { Inflation })_{i t}+\beta_{6} \operatorname{In}(\text { Population })_{i t}+\beta_{7}$ $(\text { Rule of Law Index })_{i t}+\beta_{8}$ (Control of Corruption Index $)_{i t}+\beta_{9}(\text { Country Risk Index })_{i t}+\varepsilon_{i t}$

\section{Model (6):}

$\ln (F D I)_{i t}=\beta_{1} \ln (F D I)_{i t-1}+\beta_{2} \ln (G D P)_{i t}+\beta_{3}(\text { Physical Capital })_{i t}+\beta_{4}(\text { Trade Openness })_{i t}+\beta_{5}(\text { Inflation })_{i t}+\beta_{6} \operatorname{In}(\text { Population })_{i t}+\beta_{7}$

$(\text { Rule of Law Index })_{i t}+\beta_{8}(\text { Control of Corruption Index })_{i t}+\beta_{9}(\text { Political Risk Index })_{i t}+\varepsilon_{i t}$

Model (7):

$\ln (F D I)_{i t}=\beta_{1} \ln (F D I)_{i t-1}+\beta_{2} \ln (G D P)_{i t}+\beta_{3}(\text { Physical Capital })_{i t}+\beta_{4}(\text { Trade Openness })_{i t}+\beta_{5}(\text { Inflation })_{i t}+\beta_{6} \ln (\text { Population })_{i t}+\beta_{7}$ $(\text { Rule of Law Index })_{i t}+\beta_{8}(\text { Control of Corruption Index })_{i t}+\beta_{9}(\text { Financial Risk Index })_{i t}+\varepsilon_{i t}$

\section{Model (8):}

$\ln (F D I)_{i t}=\beta_{1} \ln (F D I)_{i t-1}+\beta_{2} \ln (G D P)_{i t}+\beta_{3}(\text { Physical Capital })_{i t}+\beta_{4}(\text { Trade Openness })_{i t}+\beta_{5}(\text { Inflation })_{i t}+\beta_{6} \operatorname{In}(\text { Population })_{i t}+\beta_{7}$ $(\text { Rule of Law Index })_{i t}+\beta_{8}(\text { Control of Corruption Index })_{i t}+\beta_{9}(\text { Economic Risk Index })_{i t}+\varepsilon_{i t}$

In all models: $i=1,2, \ldots, 49$. $\quad t=2002, \ldots, 2015$.

\section{Estimation Results}

\subsection{Descriptive Statistics and Preliminary Findings}

Table 2 shows the descriptive statistics for the variables used in this study. According to the table, the average FDI inflow into the developing countries was $\$ 9.27$ billion US dollars over the period 2002-2015. The lowest FDI inflows was $\$ 73$ million US dollars into Paraguay in 2005, while the highest FDI inflows was $\$ 200.9$ billion US dollars into China in 2013 . The control of corruption variable has an average value of -0.315 . The lowest index value is -1.488 in Bangladesh, while the highest index value is 1.722 in Qatar. In light of this information, we can say that, among the countries examined during the period studied, Bangladesh is the country that ranked the lowest in terms of combatting corruption (highest corruption perception), while Qatar is the country that ranked the highest in terms of combatting corruption (lowest corruption perception).

Table 1: Descriptive Statistics of Variables

\begin{tabular}{lllllll}
\hline Variables & Mean & Std. Dev. & Minimum & [Country], [Year] & Maximum & [Country], [Year] \\
\hline FDI (Billion \$) & 9.272 & 29.413 & 0.073 & [Paraguay], [2005] & 200.928 & [China], [2013] \\
Control of Corruption In. & -0.315 & 0.579 & -1.488 & [Bangladesh], [2004] & 1.722 & [Qatar], [2009] \\
Country Risk Index & 68.599 & 6.779 & 51 & [S. Leone], [2003] & 84.5 & [Bostwana], [2007] \\
Political Risk Index & 64.117 & 8.467 & 39 & [Nigeria], [2002] & 83.5 & [Hungary], [2003] \\
Financial Risk Index & 38.175 & 4.759 & 18 & [Argentina], [2002] & 49 & [Chile], [2010] \\
Economic Risk Index & 35.050 & 4.531 & 19 & [Moldowa], [2009] & 50 & [Qatar], [2010] \\
\hline
\end{tabular}

For the period studied, the risk index values for country risk and its components (political, financial, and economic risk) average 68.5, 64.11, 38.17, and 35.05, respectively. Based on these average risk index values, we can say that the average risk in the countries included in this study is at the low-middle level. As we specified before, a low index value indicates a high risk level (and vice versa). Therefore, the highest country risk was recorded in Sierra-Leone in 2003 (index value: 51) and the lowest country risk was recorded in Botswana in 2007 (index value: 84.5). The highest political risk was observed in Nigeria in 2002 (index value: 39), while Hungary was found to be the most politically stable country (index value: 83.5). Among the countries included in the study, the highest financial risk was observed in Argentina in 2002 (index value: 18), while Chile stood out as the financially most powerful/riskless country in 2010 (index value: 49). Finally, the highest economic risk was observed in Moldova in 2009 (index value: 19). The statistics also showed that Qatar had no economic risk, especially in 2010 (index value: 50) (Table 1). Following the presentation of descriptive statistics, we used correlation analysis to get preliminary information about the relationship between the variables. The findings are shown in Table 2. 
Table 2: Correlation Coefficient Matrix

\begin{tabular}{lcc}
\hline & \multicolumn{2}{c}{$\ln ($ FDI) } \\
\cline { 2 - 3 } Control of Corruption Index & coefficient & -value \\
\cline { 2 - 3 } Country Risk Index & $0.0941^{* *}$ & {$[0.0143]$} \\
Political Risk Index & $0.2301^{* * *}$ & {$[0.0000]$} \\
Financial Risk Index & $0.0870^{* *}$ & {$[0.0236]$} \\
Economic Risk Index & $0.2720^{* * *}$ & {$[0.0000]$} \\
\hline Note: $\left({ }^{* * *}\right)$ significant at $1 \%$ level, $\left.{ }^{* *}\right)$ significant at 5\% level. & $0.2435^{* * *}$ & {$[0.0000]$} \\
\hline
\end{tabular}

The findings of correlation show that there is a positive and significant correlation between FDI inflows and Control of Corruption (0.09), Country Risk (0.23), Political Risk (0.08), Financial Risk (0.27), and Economic Risk Indices (0.24). Given the fact that an increase in the control of corrpution index means decreased corruption, and an increase in risk index means decreased level of risk, the correlation findings may indicate an inverse relationship between corruption/risk level and FDI inflows in developing countries.

\subsection{Results of Static Panel Data Analysis}

Following the correlation, we continued with the estimation of the static panel data models. First, we investigated the presence of unit and/or time effects in the models in order to select the proper model/estimator. Table 3 shows that results of the tests performed for this purpose.

Table 3: Results of Appropriate Model/Estimator Election Tests

\begin{tabular}{lllllllll}
\hline & \multicolumn{2}{c}{ Unit and Time Effect (a) } & \multicolumn{2}{c}{ Unit Effect $(\boldsymbol{b})$} & \multicolumn{2}{c}{ Time Effect $(\boldsymbol{c})$} & \multicolumn{2}{c}{ Hausman Test } \\
\cline { 2 - 8 } & F-test & LR Test & F-test & LR Test & F-test & LR Test & $\left(\chi^{2}\right)$ statistics & Probability $>\chi^{2}$ \\
\hline Model (1) & $12.74^{* * *}$ & $287.25^{* * *}$ & $12.38^{* * *}$ & $265.76^{* * *}$ & $3.83^{* * *}$ & $8.37^{* * *}$ & $19.85^{* *}$ & 0.0109 \\
Model (2) & $11.67^{* * *}$ & $264.99^{* * *}$ & $11.45^{* * *}$ & $243.47^{* * *}$ & $3.86^{* * *}$ & $10.85^{* * *}$ & $23.76^{* * *}$ & 0.0025 \\
Model (3) & $12.66^{* * *}$ & $290.75^{* * *}$ & $12.12^{* * *}$ & $261.16^{* * *}$ & $4.59^{* * *}$ & $11.90^{* * *}$ & $18.10^{* *}$ & 0.0205 \\
Model (4) & $12.35^{* * *}$ & $289.98^{* * *}$ & $12.59^{* * *}$ & $268.82^{* * *}$ & $3.68^{* * *}$ & $16.84^{* * *}$ & $16.25^{* *}$ & 0.0229 \\
\hline
\end{tabular}

Note: (**) significant at $5 \%$ level.

We first performed $\mathrm{F}$ and LR tests to investigate the presence of a unit and time effect in the models (validity of the two-way model). As a result of both tests, the null hypothesis $\left(\mathrm{H}_{0}\right)$ was rejected at the $1 \%$ level of significance, thus the presence of a unit and time effect was confirmed in all models, i.e., the validity of the two-way model was confirmed. At the second step, the presence of unit and time effects in all models were investigated separately. Similarly, the results of $F$ and LR tests showed that each static panel data model had both unit and time effects. Therefore, the tests revealed that Pooled OLS would be an inconsistent and inefficient estimator for an effective and reliable estimation. After Pooled OLS was shown to be inappropriate, the Hausman specification test was performed to determine whether the unit and/or time effect is fixed or random, i.e., whether the fixed effects or random effect model would be more suitable to estimate the relationship between the variables correctly. The significance of the Hausman $\left(\chi^{2}\right)$ test statistics was found to be smaller than 0.05 in all models. Based on these findings, we concluded that the difference between the parameters was not systematic, thus the null hypothesis $\mathrm{H}_{0}$, assuming that REM is consistent and effective, was rejected, and FEM was confirmed as effective and consistent for the estimation of all models (Table 3).

After two-way FEM was confirmed as the proper estimator for all models, the models were examined for the presence of heteroscedasticity, autocorrelation, and cross-section dependence. Table 4 shows the results of the diagnostic tests performed for this purpose. 
Table 4: Results of Diagnostic Tests

\begin{tabular}{llllccc}
\hline & \multicolumn{2}{c}{ Heteroscedasticity } & \multicolumn{2}{c}{ Autocorrelation } & \multicolumn{2}{c}{ Cross-sectional dependence } \\
\cline { 2 - 7 } Estimation models & \multicolumn{2}{c}{ M. Wald $\left(\chi^{2}\right)$ Test } & D-W Test & Baltagi-Wu (LBI) Test & Pesaran CD Test & Free's Test \\
\hline Model (1) & $3972.71^{* * * *}$ & {$[0.0000]$} & 1.29250 & 1.54556 & $5.175^{* * *}[0.0000]$ & $5.171^{* * *}$ \\
Model (2) & $3656.23^{* * *}$ & {$[0.0000]$} & 1.27656 & 1.52505 & $5.816^{* * *}[0.0000]$ & $4.951^{* * *}$ \\
Model (3) & $5608.19^{* * *}$ & {$[0.0000]$} & 1.25987 & 1.51160 & $7.707^{* * *}[0.0000]$ & $5.272^{* * *}$ \\
Model (4) & $3793.71^{* * *}$ & {$[0.0000]$} & 1.26936 & 1.52774 & $4.638^{* * *}[0.0000]$ & $5.110^{* * *}$ \\
\hline
\end{tabular}

Notes: M. Wald $\left(\chi^{2}\right)$ test; $\left[\left(\mathrm{H}_{0}: \sigma^{2}{ }^{2}=\sigma^{2}\right)\right.$. (the variance of units is homoscedasticity). [...]; indicates the probability of test statistics.

Critical values from Free's $Q$ distribution; $a=0.10: 0.3583 ; a=0.05: 0.4923 ; a=0.01: 0.7678 .(* * *)$ significant at $1 \%$ level.

As a result of the Modified Wald test performed to examine the presence of heteroscedasticity, the significance of $\left(\chi^{2}\right)$ statistics was found to be smaller than 0.05 in all models. Thus, the null hypothesis assuming the presence of homoscedasticity was rejected, and all models were confirmed to have heteroscedasticity. The results of DW and LBI tests performed to investigate the presence of autocorrelation showed that the statistics obtained from both tests were much lower than the threshold level of 2 . Therefore, all models were confirmed to have the problem of autocorrelation. To examine the presence of cross-section dependence, we performed the Pesaran $\mathrm{CD}$ test and Free's test. The findings we obtained from both tests showed that the null hypothesis assuming that there is no cross-section dependence among the units (countries) should be rejected for all models at the $1 \%$ level of significance. In other words, all models were found to have the problem of cross-section dependence (Table 4).

Since the problems of heteroscedasticity, autocorrelation, and cross-section dependence were present in all of the models, they were estimated again using the Driscoll-Kraay approach, which allows estimation with robust standard errors without changing the coefficients. Table 5 shows the findings of two-way FEM with Driscoll-Kraay standard error. Before interpreting the findings, statistical validity of the models should be tested. To this end, we first examined the overall significance of the models using the F-test and found that all models are statistically significant at $1 \%$. Moreover, the $\mathrm{R}^{2}$ statistic was found to be 0.51 in all models, which can be considered high. Therefore, all models were found to be valid, so we proceed to the interpretation of the findings.

The findings showed that the coefficients of GDP, physical capital, inflation, and the rule of law, which were included in the models as control variables, were positive and statistically significant in all models. On the other hand, the coefficient of trade openness was positive, and the coefficient of population was negative, although neither of them was statistically significant in any of the models. Based on these findings, we can say from an economic point of view that any increase in income level, physical capital, inflation, and any improvement in the legal system make developing countries attractive to foreign investors and increase FDI inflows. Furthermore, these countries' level of trade openness and population are not among the factors that affect the investment decisions of foreign investors and FDI inflows (Table 5).

After examining the control variables, we examined the findings regarding the other variables that constitute the main object of interest of this study. We found that there was a positive but statistically insignificant relationship between the control of corruption index and FDI inflows in all models. Although the level/perception of corruption does not affect FDI inflows into developing countries, the analysis showed that the risk levels of countries are one of the determinants of FDI inflows. Some studies in the literature argue that country risk is a factor that creates uncertainty and reduces profitability/return, thus negatively affecting the investment decisions of foreign investors. It is observed that this argument, which can be summarized as an inverse relationship between country risk and foreign investment inflows-i.e., countries with low risk are more attractive to foreign investors, is supported by the findings of this analysis. The results of the estimation showed that a one-unit increase in the country risk index (which indicates a decrease in country risk) increases FDI inflows into developing countries by $0.010 \%$ (Model 1 ). Similar findings were obtained from the estimation of models which include the components of country risk. Financial risk was found to be insignificant. On the other hand, a one-unit increase in political and economic risk (which indicates a decrease in political or economic risk of the country) was 
found to increase FDI inflows by $0.015 \%$ and $0.017 \%$, respectively (Model 2 and 4 ). Besides, we can say based on the empirical findings that the level of economic risk is the most important determinant for foreign investors.

Table 5: The Effects of Corruption and Country Risk on FDI Inflows: Static Panel Data Estimation

\begin{tabular}{|c|c|c|c|c|}
\hline \multirow[b]{2}{*}{ Independent Variables } & \multicolumn{4}{|c|}{ Dependent variable: In(FDI) } \\
\hline & Model (1) & Model (2) & Model (3) & Model (4) \\
\hline $\ln (G D P)$ & $\begin{array}{c}0.80534^{* * *} \\
{[4.52]}\end{array}$ & $\begin{array}{c}0.83254^{* *} \\
{[4.89]}\end{array}$ & $\begin{array}{c}0.86626^{* * *} \\
{[4.27]}\end{array}$ & $\begin{array}{c}0.82006^{* * *} \\
{[5.14]}\end{array}$ \\
\hline Physical Capital & $\begin{array}{c}0.05546^{* * *} \\
{[9.82]}\end{array}$ & $\begin{array}{c}0.05540^{* * *} \\
{[9.48]}\end{array}$ & $\begin{array}{c}0.05567^{* * *} \\
{[9.74]}\end{array}$ & $\begin{array}{c}0.05602^{* * *} \\
{[10.12]}\end{array}$ \\
\hline Trade Openness & $\begin{array}{c}0.00023 \\
{[0.08]}\end{array}$ & $\begin{array}{c}0.00077 \\
{[0.27]}\end{array}$ & $\begin{array}{c}0.00063 \\
{[0.21]}\end{array}$ & $\begin{array}{c}3.44 \mathrm{e}-06 \\
{[0.00]}\end{array}$ \\
\hline Inflation & $\begin{array}{c}0.01390^{* * *} \\
{[4.34]}\end{array}$ & $\begin{array}{c}0.01259^{* * *} \\
{[4.43]}\end{array}$ & $\begin{array}{c}0.01159^{* * *} \\
{[4.45]}\end{array}$ & $\begin{array}{c}0.01356^{* * *} \\
{[4.45]}\end{array}$ \\
\hline In(Population) & $\begin{array}{c}-0.54775 \\
{[-1.60]}\end{array}$ & $\begin{array}{c}-0.51147 \\
{[-1.43]}\end{array}$ & $\begin{array}{c}-0.47328 \\
{[-1.36]}\end{array}$ & $\begin{array}{c}-0.51121 \\
{[-1.46]}\end{array}$ \\
\hline Rule of Law Index & $\begin{array}{c}0.42653^{* * *} \\
{[2.89]}\end{array}$ & $\begin{array}{c}0.36232^{* *} \\
{[2.55]}\end{array}$ & $\begin{array}{c}0.43036^{* * *} \\
{[2.84]}\end{array}$ & $\begin{array}{c}0.44697^{* * *} \\
{[3.01]}\end{array}$ \\
\hline Control of Corruption Index & $\begin{array}{c}0.12897 \\
{[0.71]}\end{array}$ & $\begin{array}{c}0.12936 \\
{[0.69]}\end{array}$ & $\begin{array}{c}0.14069 \\
{[0.75]}\end{array}$ & $\begin{array}{c}0.11370 \\
{[0.68]}\end{array}$ \\
\hline Country Risk Index & $\begin{array}{c}0.01026^{* * *} \\
{[3.14]}\end{array}$ & & & \\
\hline Political Risk Index & & $\begin{array}{c}0.01540^{* *} \\
{[2.63]}\end{array}$ & & \\
\hline Financial Risk Index & & & $\begin{array}{c}-0.00295 \\
{[-0.34]}\end{array}$ & \\
\hline Economic Risk Index & & & & $\begin{array}{c}0.01775^{* * *} \\
{[3.61]}\end{array}$ \\
\hline Constant & $\begin{array}{c}8.19880 \\
{[1.49]}\end{array}$ & $\begin{array}{c}6.58934 \\
{[1.11]}\end{array}$ & $\begin{array}{c}6.27480 \\
{[0.98]}\end{array}$ & $\begin{array}{c}7.45888 \\
{[1.42]}\end{array}$ \\
\hline \multicolumn{5}{|l|}{ Model Summary } \\
\hline R-Squared (Within) & 0.5117 & 0.5125 & 0.5108 & 0.5119 \\
\hline F-test & 5048725.5 & 800712.5 & 204718.5 & 1796585.3 \\
\hline Probability $>(F)$ & 0.0000 & 0.0000 & 0.0000 & 0.0000 \\
\hline Cross-sections included & 49 & 49 & 49 & 49 \\
\hline Number of Observation & 675 & 675 & 675 & 675 \\
\hline
\end{tabular}

\subsection{Results of Dynamic Panel Data Analysis}

Table 6 shows the results of the dynamic panel data estimation. Before interpreting the findings, we performed the relevant tests to investigate whether the GMM estimators were effective and consistent. We first performed the Wald test and found that all models have overall statistical significance at the $1 \%$ level. Then we performed the Sargan test to test the validity of the instrumental variables. As expected, the significance of the Sargan $\left(\chi^{2}\right)$ test statistics was found to be higher than 0.05 in all models, confirming the validity of the instrumental variables for both estimators. Moreover, the results of the autocorrelation test showed that all models have firstorder autocorrelation, however, they have no second-order autocorrelation. According to the results of the diagnostic tests, both estimators are consistent, so the findings can be interpreted.

Table 6 shows that estimation coefficients are different; however, both estimators yielded the same results in terms of the direction of the relationships between the variables $(+,-)$ and their statistical significance. According to the findings, the coefficients of the variables, i.e., [In (FDI)t-1], In (GDP), physical capital, trade openness, inflation and the rule of law index, are all positive and statistically significant at $1 \%$ in all models. From these results, we can say that FDI inflows in the previous years, income level, physical capital, trade openness, inflation, and an effective legal system are determinants of investment decisions made by MNEs, and any increase in these variables makes developing countries attractive to foreign investors, thus increasing FDI inflows. 
Table 6: The Effects of Corruption and Country Risk on FDI Inflows: Dynamic Panel Data Estimation

\begin{tabular}{|c|c|c|c|c|c|c|c|c|}
\hline \multirow[b]{3}{*}{ Independent Variables } & \multicolumn{8}{|c|}{ Dependent variable: $\ln (F D I)$} \\
\hline & \multicolumn{4}{|c|}{ Two-step difference GMM (Arellano-Bond) } & \multicolumn{4}{|c|}{ Two-step system GMM (Arellano-Bover / Blundell-Bond) } \\
\hline & Model (5) & Model (6) & Model (7) & Model (8) & Model (5) & Model (6) & Model (7) & Model (8) \\
\hline $\ln (F D I)_{t-1}$ & $\begin{array}{c}0.08419^{* * *} \\
{[8.76]}\end{array}$ & $\begin{array}{c}0.04343^{* * *} \\
{[5.60]}\end{array}$ & $\begin{array}{c}0.08899^{* * *} \\
{[8.39]}\end{array}$ & $\begin{array}{c}0.10744^{* * *} \\
{[10.97]}\end{array}$ & $\begin{array}{c}0.20444^{* * *} \\
{[25.35]}\end{array}$ & $\begin{array}{c}0.21697^{* * *} \\
{[18.32]}\end{array}$ & $\begin{array}{c}0.21119^{* * *} \\
{[17.03]}\end{array}$ & $\begin{array}{c}0.19572^{* * *} \\
{[7.64]}\end{array}$ \\
\hline $\ln (G D P)$ & $\begin{array}{c}1.15156^{* * *} \\
{[30.32]}\end{array}$ & $\begin{array}{c}1.32192^{* * *} \\
{[23.97]}\end{array}$ & $\begin{array}{c}1.10111^{* * *} \\
{[24.30]}\end{array}$ & $\begin{array}{c}1.07712^{* * *} \\
{[24.47]}\end{array}$ & $\begin{array}{c}0.80334^{* * *} \\
{[19.19]}\end{array}$ & $\begin{array}{c}0.88393^{* * *} \\
{[15.31]}\end{array}$ & $\begin{array}{c}0.78126^{* * *} \\
{[15.48]}\end{array}$ & $\begin{array}{c}0.84302^{* * *} \\
{[15.06]}\end{array}$ \\
\hline Physical Capital & $\begin{array}{c}0.04348^{* * * *} \\
{[13.62]}\end{array}$ & $\begin{array}{c}0.03958^{* * *} \\
{[14.86]}\end{array}$ & $\begin{array}{c}0.04833^{* * * *} \\
{[14.21]}\end{array}$ & $\begin{array}{c}0.04647^{* * *} \\
{[15.80]}\end{array}$ & $\begin{array}{c}0.03605^{* * * *} \\
{[8.88]}\end{array}$ & $\begin{array}{c}0.03432^{* * *} \\
{[16.78]}\end{array}$ & $\begin{array}{c}0.03774^{* * *} \\
{[8.66]}\end{array}$ & $\begin{array}{c}0.03424^{* * *} \\
{[18.20]}\end{array}$ \\
\hline Trade Openness & $\begin{array}{c}0.01256^{* * *} \\
{[10.96]}\end{array}$ & $\begin{array}{c}0.01424^{* * *} \\
{[14.46]}\end{array}$ & $\begin{array}{c}0.01216^{* * *} \\
{[12.23]}\end{array}$ & $\begin{array}{c}0.00806^{* * *} \\
{[6.73]}\end{array}$ & $\begin{array}{c}0.00888^{* * *} \\
{[9.54]}\end{array}$ & $\begin{array}{c}0.01044^{* * *} \\
{[14.38]}\end{array}$ & $\begin{array}{c}0.00910^{* * *} \\
{[11.49]}\end{array}$ & $\begin{array}{c}0.00699^{* * *} \\
{[5.66]}\end{array}$ \\
\hline Inflation & $\begin{array}{c}0.01490^{* * *} \\
{[6.21]}\end{array}$ & $\begin{array}{c}0.01248^{* * *} \\
{[6.66]}\end{array}$ & $\begin{array}{c}0.01013^{* * *} \\
{[5.13]}\end{array}$ & $\begin{array}{c}0.01569^{* * *} \\
{[7.67]}\end{array}$ & $\begin{array}{c}0.02178^{* * *} \\
{[9.18]}\end{array}$ & $\begin{array}{c}0.01568^{* * *} \\
{[8.98]}\end{array}$ & $\begin{array}{c}0.01618^{* * *} \\
{[6.61]}\end{array}$ & $\begin{array}{c}0.01822^{* * *} \\
{[8.54]}\end{array}$ \\
\hline $\ln$ (Population) & $\begin{array}{c}-1.84329^{* * *} \\
{[-4.77]}\end{array}$ & $\begin{array}{c}-1.90999^{* * *} \\
{[-4.03]}\end{array}$ & $\begin{array}{c}-2.37780^{* * * *} \\
{[-5.54]}\end{array}$ & $\begin{array}{c}-1.63929^{* * *} \\
{[-5.19]}\end{array}$ & $\begin{array}{c}-0.35488^{* * * *} \\
{[-4.97]}\end{array}$ & $\begin{array}{c}-0.42479^{* * *} \\
{[-6.91]}\end{array}$ & $\begin{array}{c}-0.40334^{* * *} \\
{[-7.65]}\end{array}$ & $\begin{array}{c}-0.40833^{* * * *} \\
{[-5.36]}\end{array}$ \\
\hline Rule of Law Index & $\begin{array}{c}0.35672^{* * * *} \\
{[5.44]}\end{array}$ & $\begin{array}{c}0.45326^{* * * *} \\
{[4.84]}\end{array}$ & $\begin{array}{c}0.49010^{* * * *} \\
{[2.99]}\end{array}$ & $\begin{array}{c}0.49373^{* * * *} \\
{[4.39]}\end{array}$ & $\begin{array}{c}0.49381^{* * * *} \\
{[5.26]}\end{array}$ & $\begin{array}{c}0.72539^{* * * *} \\
{[6.31]}\end{array}$ & $\begin{array}{c}0.25508^{* * *} \\
{[2.04]}\end{array}$ & $\begin{array}{c}0.31556^{* * * *} \\
{[3.79]}\end{array}$ \\
\hline Control of Corruption Index & $\begin{array}{c}0.49498^{* * *} \\
{[7.14]}\end{array}$ & $\begin{array}{c}0.49586^{* * *} \\
{[7.51]}\end{array}$ & $\begin{array}{c}0.66063^{* * *} \\
{[14.74]}\end{array}$ & $\begin{array}{c}0.48795^{* * *} \\
{[7.67]}\end{array}$ & $\begin{array}{c}0.56851^{* * *} \\
{[7.62]}\end{array}$ & $\begin{array}{c}0.49842^{* * *} \\
{[7.01]}\end{array}$ & $\begin{array}{c}0.63669^{* * *} \\
{[7.02]}\end{array}$ & $\begin{array}{c}0.57069^{* * *} \\
{[4.15]}\end{array}$ \\
\hline Country Risk Index & $\begin{array}{c}0.028111^{* * *} \\
{[7.67]}\end{array}$ & & & & $\begin{array}{c}0.03060^{* * *} \\
{[8.80]}\end{array}$ & & & \\
\hline Political Risk Index & & $\begin{array}{c}0.04083^{* * *} \\
{[11.91]}\end{array}$ & & & & $\begin{array}{c}0.03936^{* * *} \\
{[12.97]}\end{array}$ & & \\
\hline Financial Risk Index & & & $\begin{array}{c}0.01083^{* * *} \\
{[2.77]}\end{array}$ & & & & $\begin{array}{c}-0.00234 \\
{[-0.79]}\end{array}$ & \\
\hline Economic Risk Index & & & & $\begin{array}{c}0.04995^{* * *} \\
{[17.65]}\end{array}$ & & & & $\begin{array}{c}0.05481^{* * *} \\
{[19.20]}\end{array}$ \\
\hline \multicolumn{9}{|l|}{ Diagnostic Tests } \\
\hline Wald $\left(x^{2}\right)$ Test & $14039.62^{* * *}$ & $15539.90^{* * *}$ & $8720.89^{* * *}$ & $62226.91^{* * *}$ & $10126.83^{* * *}$ & $21202.42^{* * *}$ & $25012.04^{* * *}$ & $9986.20^{* * *}$ \\
\hline Probability > Wald $\left(X^{2}\right)$ & 0.0000 & 0.0000 & 0.0000 & 0.0000 & 0.0000 & 0.0000 & 0.0000 & 0.0000 \\
\hline Sargan $\left(x^{2}\right)$ Test & 45.5738 & 46.4331 & 41.9147 & 46.3287 & 41.0884 & 39.05782 & 43.0768 & 42.7358 \\
\hline Probability > Sargan $\left(x^{2}\right)$ & 0.8389 & 0.8152 & 0.9189 & 0.8182 & 0.9960 & 0.9981 & 0.9921 & 0.9929 \\
\hline $\operatorname{Ar}(1),($ probability value $>z)$ & 0.0007 & 0.0013 & 0.0020 & 0.0008 & 0.0007 & 0.0006 & 0.0011 & 0.0013 \\
\hline $\operatorname{Ar}(2)$, (probability value $>z)$ & 0.6287 & 0.8876 & 0.5380 & 0.4383 & 0.3156 & 0.3065 & 0.2751 & 0.2496 \\
\hline Number of Instrumental Var. & 66 & 66 & 66 & 66 & 78 & 78 & 78 & 78 \\
\hline Cross-sections included & 49 & 49 & 49 & 49 & 49 & 49 & 49 & 49 \\
\hline Number of Observation & 569 & 569 & 569 & 569 & 621 & 621 & 621 & 621 \\
\hline
\end{tabular}

Notes: ${ }^{(* * *)}$ significant at $1 \%$ level. Value of $z$-statistics in [...] parentheses. 
Differing from the analysis of the static panel data, the results of the dynamic panel data analysis revealed that the coefficient of the Control of Corruption index was positive and statistically significant at $1 \%$ in all models. Given the fact that any increase in the Control of Corruption index indicates a decrease in the level of corruption, we can say that reduction (increase) of the level of corruption increases (reduces) FDI inflows in developing countries. This finding also reveals that the grabbing-hand theory, which assumes that corruption activities increase costs and uncertainty, like a tax, thus reducing FDI inflows, is valid for the developing countries studied. The coefficient of country risk, which is used to represent the overall risk level of countries, was also found to be positive and significant. The two-step difference GMM and twostep system GMM estimation showed that a one-unit increase in country risk index increases FDI inflows by $0.028 \%$ and $0.030 \%$, respectively. Considering that an increased index value means a decrease in the level of risk, this finding strongly supports the theory that "the risk level of host countries is a factor that affects the investment decisions of investors negatively; therefore, foreign investors prefer countries with low level of risk." Among the components of country risk, political risk and economic risk were found to be the variables for which the inverse relationship between risk and FDI inflow is also valid. According to the two-step system GMM estimator, financial risk does not have any significant effect on FDI inflows, while the results of the two-step difference GMM estimation showed that decreased financial risk has a weak but positive effect on FDI inflows. Finally, as revealed by the static panel data analysis, the most important determinant of the investment decisions of MNEs was found to be economic risk.

\section{Conclusion and Recommendations}

FDI is recognized by developing countries with a low level of savings and capital stock as an important source of external financing for growth and development. Therefore, such countries try to attract as much FDI as possible. However, these countries fail in attracting the desired level of FDI inflows as well as experiencing capital flight. Studies conducted to examine the reasons why some countries have trouble in attracting FDI found that economic and institutional structures in these countries have an effect on the investment decisions of MNEs. Although the theoretical literature gives various views about this issue, there is a common view that a high level of corruption and risk reduces FDI inflows into developing countries. However, it is observed that empirical findings vary to a great extent, and no consensus has been reached yet on the effects of corruption and risk on FDI inflows. This study analyzed the effect of corruption and country risk on FDI inflows in 49 developing countries over the period from 2002-2015 using static (fixed effects) and dynamic (two-step difference GMM and two-step system GMM) panel data analysis. The empirical findings demonstrated that: i) decreased corruption and country risk increases FDI, ii) financial risk has no significant effect on FDI inflows, while decreased economic and political risk accelerate FDI inflows, and iii) FDI inflows are most sensitive to economic risk. Based on these findings, we can make some policy recommendations to developing countries in order to attract more FDI:

1. Considering that corruption is an indicator of low institutional quality, it is extremely important to establish an effectively functioning, high-quality institutional structure to control or reduce corruption. In this sense, practices such as refraining from imposing procedures that prevent or restrict foreign companies from doing business freely, increasing the efficiency of public administration by making it transparent and accountable, and freeing bureaucratic structures from red-tape will reduce corruption activities and costs (increasing profitability), thus making developing countries more attractive to foreign investors.

2. A stable macroeconomic structure should be established. In this sense, improvements in the macroeconomic indicators such as economic growth, exchange rate, budget balance, current account balance, and external debts will reduce the economic risk perception of foreign investors towards developing countries, thus increasing FDI inflows. Policies 
towards foreign capital are also taken into account by foreign investors because they prefer the countries they trust politically. Therefore, governments of developing countries should refrain from imposing arbitrary procedures and implementation policies that will create uncertainty, such as nationalization or expropriation of foreign assets. Besides, it should not be forgotten that instabilities such as terror and violence ruin the investment climate and increase the perception of political risk.

\section{References}

Abed, T. G. and Davoodi, H. R. (2000). Corruption, Structural Reforms, and Economic Performance in the Transition Economies. IMF Working Paper (00/132).

Akay, Ç. E. (2015). Dinamik Panel Veri Modelleri, Selahattin Güriş (Ed.). Stata ile Panel Veri Modelleri (1 Baskı), İstanbul: DER Yayınları.

Akbar, A., Imdadullah, M., Ullah, A. M. and Aslam, M. (2011). Determinants of Economic Growth in Asian Countries: A Panel Data Perspective. Pakistan Journal of Social Sciences, 31(1), 145157.

Akçay S. (2001). Is Corruption an Obstacle for Foreign Investors in Developing countries?: A CrossCountry Evidence. Yapı kredi Economic Review, 12, 27-34.

Alemu, M. A. (2012). Effects of Corruption on FDI Inflow in Asian Economies. Seoul Journal of Economics, 25(4), 387-412.

Ali, M.A., Asfand, A.Y.K., Bakhtiyar, B.K., and Hammad, R.H.A. (2014). Financial Risk and Foreign Direct Investment: Evidence from Pakistan Economy. International Journal of Business Management and Economic Studies, 1(1), 52-68.

Alimi, R. S. (2015). Financial Deepening and Economic Growth: A System GMM Panel Analysis with Application to 7 SSA Countries. Munich Personal RePEc Archive, 1-12.

Al-Jaifi, A., Abdullah, H. A. N. and Regupathi, A. (2016). Risks and Foreign Direct Investment Inflows: Evidence from Yemen. Jurnal Pengurusan, 46, 89 - 97.

Al-Sadiq, A. (2009). The Effects of Corruption on FDI Inflows. Cato Journal, 29(2), 267-294.

Amundsen, I. (1999). Political Corruption: An Introduction to the Issues, Chr. Michelsen Institute Development Studies and Human Rights, Working Paper Series, No. 7, s. 1-33.

Ardiyanto, F. (2012). Foreign Direct Investment and Corrruption (Unpublished doctoral dissertation). Colorado State University, Fort Collins, Colorado.

Arellano, M. and Bond, S. (1991). Some Tests of Specification for Panel Data: Monte Carlo Evidence and an Application to Employment Equations. The Review of Economic Studies, 58(2), $277-$ 297.

Arellano, M. and Bover, O. (1995). Another Look at the Instrumental Variable Estimation of ErrorComponents Models. Journal of Econometrics, 68(1), 29-51.

Azam, M. and Ahmad, S. A. (2013). The Effects of Corruption on Foreign Direct Investment Inflows: Some Empirical Evidence from Less Developed Countries. Journal of Applied Sciences Research, 9(6), 3462-3467.

Azam, M. and Khattak, N. R. (2009). Social and Political Factors Effects on Foreign Direct Investment in Pakistan (1971-2005). Gomal University Journal of Research, 25(1), 46-50 47.

Baek, K. and Qian, X. (2011). An Analysis on Political Risks and the Flow of Foreign Direct Investment in Developing and Industrialized Economies. Economics, Management and Financial Markets, 6(4), 60-91. 
Balboa, J. and Medalla, M. E. (2006). Anti-Corruption and Governance: The Philippine Experience. APEC Study Center Consortium Conference, 1-28, Ho Chi Minh City, Viet Nam.

Baltagi H. B. (2005), Econometric Analysis of Panel Data (3th Ed.). New york: John Wiley \& Sons.

Baltagi, B. H. and P. X. Wu (1999). Unequally Spaced Panel Data Regressions With AR(1) Disturbances. Econometric Theory, 15, 814-823.

Barassi, R. M. and Zhou, Y. (2012). The Effect of Corruption on FDI: A Parametric and Nonparametric Analysis. European Journal of Political Economy, 28, 302-312.

Baum, F. C. (2006). An Introduction to Modern Econometrics Using Stata (First Ed.). Texas: Stata Press Publication.

Bhargava, A., Franzini, L., and Narendranathan, W. (1982). Serial Correlation and Fixed Effect Model. The Review of Economic Studies, 49(4), 533-549.

Blundell, R. and Bond, S. (1998). Initial Conditions and Moment Restrictions in Dynamic Panel Data Models. Journal of Econometrics, 87(1), 115-143.

Bond, R. S. (2002). Dynamic Panel Data Models: A Guide to Micro Data Methods and Practice. Cemmap working paper, CWP09/02.

Bond, R. S., Hoeffler, A. and Temple, J. (2001). GMM Estimation of Empirical Growth Models. CEPR Discussion Paper Series, No. 3048, 1-33.

Borensztein, E., Gregorio, D. J. and Lee, J-W. (1998). How Does Foreign Direct Investment Affect Economic Growth?. Journal of International Economics, 45, 115-135.

Brada, J., Drabek, Z. and Perez, M. (2012). The Effect of Home-Country and Host-Country Corruption on Foreign Direct Investment. Review of Development Economics, 16(4), 640663.

Bun, G. J. M. and Windmeijer, F. (2009). The Weak Instrument Problem of the System GMM Estimator in Dynamic Panel Data Models. UVA Econometrics, Discussion Paper, 01, 1-47.

Busse, M. and Hefeker, C. (2007). Political Risk, Institutions and Foreign Direct Investment. European Journal of Political Economy, 23(2), 397-415.

Carstensen, K. and Toubal, F. (2004). Foreign Direct Investment in Central and Eastern European Countries: A Dynamic Panel Analysis. Journal of Comparative Economics, 32(1), 3-22.

Castro, C. and Nunes, P. (2013). Does Corruption Inhibit Foreign Direct Investment?. Politica / Revista de Ciencia Politica, 51(1), 61-83.

Choi, W-S. and Samy, Y. (2008). Reexamining the Effect of Democratic Institutions on Inflows of Foreign Direct Investment in Developing Countries. Foreign Policy Analysis, 4(1), 83-103.

Desbordes, R. (2009). Global and Diplomatic Political Risks and Foreign Direct Investment. Economics \& Politics, 22(1), 92-125.

Duasa, J. and Kassim, H. J. (2009). Foreign Portfolio Investment and Economic Growth in Malaysia. The Pakistan Development Review, 48(2), 109-123.

Egger, P. and Winner, H. (2005). Evidence on Corruption as an Incentive for Foreign Direct Investment. European Journal of Political Economy, 21, 932- 952.

Elekwa, P., Anıebo, C. and Ogu, C. (2016). Does Foreign Portfolio Investment Affect Employment Growth in Nigeria?. Journal of Economics and Sustainable Development, 7(12), 81-84. 
Elleuch, N.M., Jaouadi, I.Z. and Jaouadi, S. (2015). Examination of Impact of Political and Country Risk on Foreign Direct Investment Inflows in Tunisia. European Academic Research, 2(11), 14434-14445.

Fahad, Y. A. and Ahmed, M. (2016). The Impact of Corruption on Foreign Direct Investment (FDI) in Post-Conflict Countries: A Panel Causality Test. Journal of Advanced Social Research, 6(3), 1-12.

Gujarati, N. D. (2003), Basic Econometrics (4th Ed.). New York: McGraw Hill Educations.

Gupta, P. and Singh, A. (2016). Determinants of Foreign Direct Investment Inflows in BRICS Nations: A Panel Data Analysis. Emerging Economy Studies, 2(2), 181-198.

Habib, M. and Zurawicki, L. (2002). Corruption and Foreign Direct Investment. Journal of International Business Studies, 33(2), 291-307.

Hayakawa, K., Kimura, F. and Lee, H. (2011). How Does Country Risk Matter for FDI. Institute of Developing Economies. Paper, (281).

Helmy, E. H. (2013). The Impact of Corruption on FDI: is MENA an Exception?. International Review of Applied Economics, 27(4), 491-514.

Hill, R. C., Griffiths, W. E., and Lim, G. C. (2011). Principles of Econometrics (4th ed.). United States of America: John Wiley \& Sons.

Hossain, S. (2016). Foreign Direct Investment (FDI) and Corruption: Is it a Major Hindrance for Encouraging Inward FDI?. African Journal of Business Management, 10(10), 256-269.

Hsiao, C. (2003). Analysis of Panel Data (2th ed.). Cambridge: Cambridge University Press.

IMF (2008). Globalization: A Brief Overview, Issue 02/08. (https://www.imf.org/ external/np/exr/ib/2008/pdf/053008.pdf).

IMF (2014). The Role of Country Concentration in the International Portfolio Investment Positions for the European Union Members. IMF Working Paper 14/74.

Jadlav, P. (2012). Determinants of Foreign Direct Investment in BRICS Economies: Analysis of Economic, Institutional and Political Factor. Procedia- Social and Behavioral Sciences, 37, 5 - 14.

Jiménez, A. (2011). Political Risk as a Determinant of Southern European FDI in Neighboring Developing Countries. Emerging Markets Finance and Trade, 47(4), 59-74.

Kariuki, C. (2015). The Determinants of Foreign Direct Investment in the African Union. Journal of Economics, Business and Management, 3(3), 346-351.

Kendall, T. and Zhou, Y. (2009). The Impact of Corruption on FDI. (https://editorialex press.com/cgibin/conference/download.cgi?db_name=serc2009\&paper_id=212).

Lee, H. H. and Rajan, S. R. (2009). Cross-Border Investment Linkages among APEC Economies: The Case of Foreign Direct Investment. Asia-Pacific Economic Cooperation Policy Support Unit.

Li, H. and Zhang, J. (2007). Do High Birth Rates Hamper Economic Growth?. The Review of Economics and Statistics, 89(1), 110-117.

Li, Q. and Resnick, A. (2003). Reversal of Fortunes: Democratic Institutions and Foreign Direct Investment Inflows to Developing Countries. International Organization, 57, 175-211.

Lopez-M.-A. (1999). Large Capital Flows Causes, Consequences, and Policy Responses. IMF Working Paper 99/17.

Maddala G. S (2001). Introductions to Econometrics (3th Ed.). England, John Wiley \& Sons. 
Meldrum, H. (2000). Country Risk and Foreign Direct Investment. Business Economics, 35(1), 3340.

Midoun, S. and Zairi, B. (2015). Country Risk Components Effects On Algeria Attractiveness for Foreign Direct Investment (1990-2012). El-Bahith Review, 15, 19-30.

Musonera, E. (2008). Country Risk Factors: An Empirical Study of FDI Determinants in SSA. Journal of International Management Studies, 3(1), 1-9.

Ohlsson, H. M. (2007). Impact of Corruption on FDI - A Cross Country Analysis (Unpublished Master's Thesis), Jönköping University, Jönköping.

Pal, P. (2006). Foreign Portfolio Investment, Stock Market and Economic Development: A Case Study of India. Annual Conference on Development and Change Mission: Promoting Development in a Globalized World, 1-24, Sao Paulo, Brazil.

Pfister (2010). The Effect of Social Trust and Economic Growth (Unpublished Master Thesis), Aarhus University, Aarhus, Denmark.

Popescu, H. G. (2014). FDI and Economic Growth in Central and Eastern Europe. Sustainability, 6, 8149-8163.

Prasad, E., Rogoff, K., Wei, J. S. and Köse, A. M. (2003), Effects of Financial Globalization on Developing Countries: Some Empirical Evidence. IMF Occasional Paper 220.

PRS (2014). International Country Risk Guide Methodology. East Syracuse, NY: PRS Group.

Quazi, M. R. (2014). Corruption and Foreign Direct Investment in East Asia and South Asia: An Econometric Study. International Journal of Economics and Financial Issues, 4(2), 231-242.

Quazi, R., Vemuri, V. and Soliman, M. (2014). Impact of Corruption on Foreign Direct Investment in Africa. International Business Research, 7(4), 1-10.

Ramcharran, H. (1999). Foreign Direct Investment and Country Risk: Further Empirical Evidence. Global Economic Review, 28(3), 49-59.

Ravi, P. S. (2015). Does Corruption in a Country Affect the Foreign Direct Investment? A Study of Rising Economic Super Powers China and India. Open Journal of Social Sciences, 3, 99-104.

Sanjo, Y. (2012). Country Risk, Country Size, and Tax Competition for Foreign Direct Investment. International Review of Economics \& Finance, 21(1), 292-301.

Sedik, W. M. (2012). The Impact of Country Risk and New Institutional Economics on Foreign Direct Investment: A Panel Data Analysis for Middle East and North Africa Region. The 16th Meeting of the International Society for New Institutional Economics, University of Southern California, USA.

Shapiro, A. (1999), Multinational Financial Management (6th Ed.). London: Prentice Hall.

Soto, M. (2009). System GMM Estimation with A Small Number of Individuals. (http//citeseerx.ist.psu.edu/viewdoc/download?doi=10.1.1.465.9928\&rep=rep1\&type=p df).

Söderbom, M. (2011). Econometrics II, Lecture 6: Panel Data Part I. (http://www. soderbom.net/metrix2/lec6_7.pdf).

Tatoğlu, F. Y. (2012), Panel Veri Ekonometrisi (1. Baskı), İstanbul: Beta Yayınevi.

Teixeira, C. A. A. and Guimarães, L. (2015). Corruption and FDI: Does the Use of Distinct Proxies for Corruption Matter?. Journal of African Business, 16(1-2), 159-179. 
Tokunova, S. Y. (2014). A Comparative Study on the Effects of Corruption on FDI (Unpublished Master Thesis), Erasmus University, Rotterdam.

Topal, H. M. and Gül, S. Ö. (2016). The Effect of Country Risk on Foreign Direct Investment: A Dynamic Panel Data Analysis for Developing Countries. Journal of Economics Library, 3(1), 141-155.

Vijayakumar, N., Perumal, S. and Rao, K. C. (2010). Determinants of FDI in BRICS countries: A panel Analysis. International Journal of Business Science and Applied Management, 5(3), 1-13.

Wei, J. S. (1997). Why is Corruption so Much More Taxing than Tax? Arbitrariness Kills. NBER Working Paper Series No. 6255, 1-17.

White, C.M. and Fan, M. (2006). Risk And Foreign Direct Investment (First Ed.). New York: Palgrave Macmillan.

World Bank (2000), Governance and Anticorruption (Chapter 6), The Quality of Growth, New York: Oxford University Press Inc.

Worldbank (2017). Combating Fraud and Corruption. (www.ifc.org/wps/wcm/connect/Topics ExtContent/IFCExternal CorporateSite/ACHome/).

www.transparency.org/what-is-corruption/\#define.

Wyk, V. J. and Lal, K. A. (2008). Risk and FDI Flows to Developing Countries. SAJEMS, 11(4), 511528. 